\title{
PENERAPAN AKAD WADI'AH PADA PRODUK SIMPANAN IDUL FITRI DI LKMA SYARI'AH AMANAH MANDIRI DESA SEKARPUTEH KECAMATAN BAGOR KABUPATEN NGANJUK
}

\author{
Oleh \\ Dewi Fitrotus Sa'diyah \\ Institut Agama Islam Pangeran Diponegoro Nganjuk
}

\begin{abstract}
Akad wadi'ah is the principle of Islamic economy in carrying out economic activities. Every Islamic financial institution is required to carry out banking activities with Islamic sharia principles, especially in terms of service. One of them is the implementation of the Wadi'ah contract on the products of Eid Al Fitr deposits in the LKN Syari'ah Amanah Mandiri. Wadi'ah is the property entrusted to those who want to practice it without being charged a penny. Along with the development of the times it turns out that the community utilizes the concept of this contract by saving for the needs of Eid al-Fitr. It's common knowledge that once a year Islamic celebration needs a lot of money. It does not look young, rich, poor, unmarried or married, surely spending in this moment is more than before. Therefore, lately people save the next year for the needs of Eid al-Fitr. This is interesting to be studied and reviewed in terms of Islamic economics.
\end{abstract}

Keywords: Akad Wadi'ah, Savings of Idul Fitri, Islamic Economics

\begin{abstract}
Abstrak
Akad wadi'ah merupakan prinsip ekonomi Islam dalam menjalankan aktifitas perekonomian. Setiap lembaga keuangan Islam dituntut menjalankan aktifitas perbankan dengan prinsip-prinsip syari'ah Islam, terutama dalam hal pelayanan. Salah satunya dengan penerapan akad wadi'ah pada produk simpanan idul fitri yang ada di LKMA Syari'ah Amanah Mandiri. Wadi'ah adalah harta yang dititipkan kepada pihak
\end{abstract}


yang mau mengamalkannya tanpa dibebani biaya sepeserpun. Seiring perkembangan zaman ternyata masyarakat memanfaatkan adanya konsep akad ini dengan menabung untuk keperluan Hari Raya Idul Fitri. Sudah rahasia umum jika perayaan Islam satu tahun sekali tersebut perlu banyak biaya. Tak pandang tua muda, kaya miskin, belum menikah atau sudah menikah pasti pengeluaran pada moment ini lebih banyak dari sebelumnya. Oleh karena itu, belakangan masyarakat menabung satu tahun ke depan untuk keperluan hari raya Idul Fitri. Hal ini menarik untuk diteliti dan ditinjau dari sisi ekonomi syariah.

Kata Kunci: Akad Wadi'ah, Simpanan Idul Fitri, Ekonomi Syariah

\section{Pendahuluan}

Perkembangan kehidupan masyarakat dari waktu ke waktu semakin berkembang pesat sebagai suatu dampak dari era keterbukaan (globalisasi) yang cenderung mengakibatkan batas-batas geografis. Seiring dengan hal tersebut diikuti pula oleh perkembangan aspekaspek kehidupan masyarakat itu sendiri. Seperti perkembangan bidang sosial, budaya, dan ekonomi.

Lembaga keuangan merupakan sesuatu yang tidak dapat dipisahkan dari kegiatan ekonomi masyarakat. Dimana didalamnya terjadi suatu penghimpunan dana dari masyarakat, kemudian dana tersebut kembali disalurkan kemasyarakat untuk berbagai macam kebutuhan, misalnya untuk keperluan investasi maupun pembiayaan.

Seperti yang kita ketahui bahwa lembaga keuangan di indonesia dibagi menjadi dua kelompok besar, yaitu lembaga keuangan konvensional dan lembaga keuangan syari'ah. Lembaga keuangan konvensional dapat diartikan sebagai suatu lembaga keuangan yang menjalankan kegiatannya berdasarkan prinsip-prinsip konvensional atau prinsip pada umumnya yang telah lama dianut masyarakat dunia. ${ }^{71}$ Pada awalnya dalam kehidupan perekonomian bangsa indonesia eksistensi lembaga keuangan konvensional lebih

\footnotetext{
${ }^{71}$ Harian Bisnis News, Hari senin 02 April 2018.
} 
dikenal dibanding lembaga keuangan syari'ah. Sekian dekade lamanya kiprah lembaga keuangan konvensional begitu merajai kehidupan perekonomian masyarakat indonesia. Namun pada akhir-akhir ini lembaga keuangan konvensional beserta segala sistem yang berada didalamnya dianggap mengandung banyak kekurangan. Anggapan ini tidak hanya datang dari kaum-kaum muslim yang notabenya menganut paham ekonomi islam, tapi berbagai kalangan yang berasal dari berbagai latarbelakang pun mengutarakan hal yang serupa. Lembaga keuangan konvensional dianggap menguntungkan atau merugikan salah satu pihak dengan proposi yang tidak tepat, tidak melindungi kaum lemah dan dibangun diatas sistem yang rapuh. Pandangan tersebut merupakan suatu hal yang tidak berlebihan, karena harus diakui dibalik perkembangannya yang begitu pesat. Lembaga keuangan konvensional dapat diumpamakan suatu bangunan yang keropos, banyak sekali kelemahan didalamnya, terlebih lagi sebagai seorang muslim kita harus berani mengatakan bahwa lembaga keuangan konvensional mengandung sistem bunga, dimana segala kelebihan/bunga yang diperjanjikan adalah riba. ${ }^{72}$ Dan riba adalah haram, sebagaimana diaur dalam Al-Qur'an Surat Al-Baqarah ayat 275-279, Ali Imran ayat 130, Annisa' ayat 161, dan Ar-Rum ayat $39 .^{73}$

Hal itulah yang melatarbelakangi lahirnya lembaga keuangan syari'ah di Indonesia bahkan dilingkap dunia. Lembaga keuangan syari'ah dianggap mampu mengatasi segala kelemahan yang terdapat dalam lembaga keuangan konvensional karena dianggap lebih arif, lebih adil dan sesuai dengan segala kondisi masyarakat. Selain itu terdapat alasan lain yang fundamental yakni larangan agama islam untuk memungut maupun meminjam dengan bunga serta larangan untuk usaha-usaha yang dikategorikan haram, dimana hal ini tidak dijamin oleh sistem konvensional. ${ }^{74}$ Terlepas dari banyak kalangan menilai jika masyarakat di indonesia "terlambat" menyadari dari

\footnotetext{
${ }^{72}$ Mutimatun Nia'mi, SH. Kuliah Muamalah. Fakultas Hukum Univeritas Muhammadiyah Surakarta, Tahun Ajaran 2012-2013.

${ }^{73}$ Al-Qur'at surat........

${ }^{74}$ Artikel Wikepedia, Perbankan Syari'ah. Hari Rabu Tanggal 25 November 2009.
} 
kebaikan sistem lembaga keuangan syari'ah, namun hal ini tetap merupakan angin segar bagi perekonomian indonesia dalam rangka perwujutan perbaikan ekonomi umat. Dan lembaga keuangan syari'ah muncul sebagai jalan keluar terbaik dalam suatu perkembangan masyarakat indonesia yang dinamis dalam bidang ekonomi dan keuangan. ${ }^{75}$

Lembaga keuangan syari'ah seperti perbankan syari'ah di indonesia keberadaannya telah diatur dalam undang-undang 7 tahun 1992 tentang perbankan. Hingga tahun 2007 terdapat 3 institusi bank syari'ah di indonesia Bank Muamalat Indonesia, Bank Syari'ah Mandiri dan Bank Mega Syari'ah, sementara itu bank umum yang telah memiliki unit usaha syari'ah adalah 19 Bank. Sistem syari'ah juga telah digunakan oleh Bank Perkreditan Rakyat, saat ini telah berkembang 104 BPR syari'ah. ${ }^{76}$ Perbankan syari'ah tersebut mempunyai beberapa produk dalam kegiatannya yaitu : ijarah (sewa menyewa). 'ariyah (pinjam meminjam), ae rahn (gadai), wadiah (penitipan). Ijarah artinya upah, sewa, jasa atau imbalan. 'ariyah artinya sesutau yang dipinjam, pergi dan kembali atau beredar (perbuatan seseorang yang membolehkan atau mengizinkan orang lain untuk mengambil manfaat barang miliknya tanpa ganti rugi). Ar rahn artinya menahan salah satu harta milik si peminjam sebagai jaminan atas pinjaman yang diterima (barang yang ditahan memiliki nilai ekonomis), dengan demikian pihak yang menahan memperoleh jaminan untuk dapat mengambil kembali seluruh atau sebagian utangnya. Sedangkan wadi'ah artinya memanfaatkan sesuatu ditempat yang bukan pada pemiliknya untuk dipelihara (dalam bahasa indonesia disebut titipan).

Kendatipun perbankan syari'ah melalui program-programnya telah mensosialisasikan produk syari'ah ke masyarakat, namun masih ada sebagian masyarakat yang belum memahami beberapa produk syari'ah, padahal apabila dikaji tentang manfaatnya, semua produk

\footnotetext{
${ }^{75}$ Majelis Ulama Indonesia “Keputusan Dewan Syari'ah Nasional NO. 1 Tahun 2000”, Dasar Pemikiran ke-3.

${ }^{76}$ Artikel Wikepedia.
} 
syari'ah tentunya mempunyai fungsi dan perannya masing-masing dalam kehidupan ekonomi umat. Sebagai salah satu produk syari'ah adalah wadi'ah (jasa penitipan) adalah jasa penitipan dana dimana penitip dapat mengambil dana tersebut sewaktu-waktu, dimana bank tidak berkewajiban namun diperbolehkan memberi bonus kepada pihak nasabah. ${ }^{77}$ Dalam perekembangannya produk wadi'ah terasa kurang populer dikalangan masyarakat. Hanya sebagian masyarakat mengetahui tentang apa yang dimaksud dengan wadi'ah, bagaimana prosedur untuk menikmati produk wadi'ah dilingkungan perbankan syari'ah serta bagaimana bentuk dan isi perjanjian wadi'ah. Sehingga perlu dilakukan pengenalan lebih lanjut kepada masyarakat akan produk-produk perbankan syari'ah dalam rangka perbaikan ekonomi serta kemaslahatan umat. LKMA Syari'ah Amanah Mandiri merupakan salah satu koperasi syari'ah yang melaksanakan tabungan hari raya. Dengan demikian LKMA turut serta berpartisipasi dalam memberikan solusi bagi masyarakat dengan cara mengelurkan produk tabungan yang bernama Tabungan Idul Fitri.

Tabungan Idul Fitri merupakan simpanan bulan dengan pembayaran pembukaan awal Rp. 10.000,- dan angsuran setiap bulannya tidak ditetapkan berapa nominal yang harus disetorkan (tergantung kemauan nasabah). Untuk pengambilannya pun juga sudah ditentukan jatuh temponya yaitu dengan cara penarikan secara serentak pada waktu dua minggu sebelum hari raya idul fitri. Tidak hanya mengambil dari tabungan idul fitri saja, namun nasabah juga mendapatkan bonus dan bagi nasabah yang beruntung akan mendapatkan doorprize berupa hadiah peralatan rumah tangga. ${ }^{78}$

\section{Metode Penelitian}

Pendekatan yang digunakan dalam penelitian ini adalah pendekatan kualitatif deskriptif, maksudnya data yang dikumpulkan berupa kata-kata, gambar, dan bukan angka-angka. Hal itu disebabkan oleh adanya penerapan metode kualitatif. Selain itu, semua yang

\footnotetext{
${ }^{77}$ Ibid.

${ }^{78}$ Modul LKMA Syari'ah Amanah Mandiri Sekarputeh
} 
dikumpulkan berkemungkinan menjadi kunci terhadap apa yang sudah diteliti. Penelitian ini dilaksanakan dengan pendekatan kualitatif, yaitu penelitian yang data-datanya berupa kata-kata (bukan angka-angka) yang berasal dari wawancara, catatn laporan, dokumen, dan lain-lain, penelitian yang didalamnya mengutamakan untuk mendeskripsikan secara anailis sesuatu peristiwa atau proses sebagaimana adanya dalam lingkungan yang alami untuk memperoleh makna yang mendalam dari proses tersebut. Menurut Bogdan dan Taylor mendeskripsikan metode kualitatif sebagai prosedur penelitian yang menghadirkan data deskriptif berupa kata-kata tertulis atau lisan dari orang-orang atau perilaku yang dapat diamati. ${ }^{79}$

Pendekatan kualitatif digunakan untuk mengungkapkan daya deskriptif dari informarsi tentang apa yang mereka lakukan, dan yang mereka alami terhadap fokus penelitian. Penelitian kualitatif memiliki karakteristik antara lain: ilimiah, manusia sebagai instrumen, menggunakan metode kualitatif, analisis data secara induktif, deskriptif, lebih mementingkan proses daripada hasil, adanya fokus, adanya kriteria untuk keabsahan data, desain penelitian bersifat sementara, dan hasil penelitian dirundingkan dan disepakati bersama. ${ }^{80}$

Jenis penelitian yang digunakan dalam penelitian ini adalah studi kasus. Dalam hal ini Nana Syaodih Sukmadinata menjelaskan bahwa studi kasus (case study) merupakan studi penelitian yang dilakukan terhadap suatu kesatuan sistem. Kesatuan ini dapat berupa program, kegiatan, peristiwa atau sekelompok individu yang terkait oleh tempat, waktu, atau ikatan tertentu. Secara singkatnya, studi kasus suatu penelitian yang diarahkan untuk menhimpun data, mengambil makna, memperoleh pemahaman dari kasus tersebut. ${ }^{81}$

Kegiatan pokok dalam penelitian ini adalah mendeskripsikan dan menganalisis secara intensif tentang segala fenomena sosial yang

\footnotetext{
${ }^{79}$ Moleong Lexy, Metodologi Penelitian Kualitatif, Bandung: Remaja Rosdakarya, 2009.

${ }^{80} \mathrm{Ibid}, \ldots$

${ }^{81}$ Nana Syaodih Sukmadinata, Metodologi Penelitian Kualitatif, Bandung: Remaja Rosdakarya, 2009.
} 
diteliti, yaitu mengenai masalah-masalah yang berkaitan dengan penerapan akad wadi'ah pada produk simpanan hari raya idul fitri yang diperoleh secara kualitatif. Penelitian ini bukan bersifat kuantitatif yang berbentuk angka-angka. Penelitian ini dapat dideskripsikan sebagai penelitian kualitatif.

\section{Teori Dan Pembahasan}

\section{A. Pengertian Wadi'ah}

Istilah "wadi'ah" berasal dari kata kerja "wada'a", yang artinya menyerahkan, menitipkan, menimpan. Menurut para ulama Syafi'i dan Maliki, wadi'ah merupakan gambaran penjagaan kepemilikan barang-barang pribadi yang penting dengan suatu cara tertentu. Para ulama Hambali menambahkan elemen amal ketika mendefinisikan wadi'ah, sebagai gambaran penjagaan (harta orang lain) dan dilakukan oleh penjaga sebagai amal. Secara singkat, wadi'ah adalah segala harta yang diserahkan oleh pemilik atau wakil pemilik kepada pihak lain agar menjaganya. Tindakan ini dilakukan atas dasar amal. ${ }^{82}$

Secara bahasa, wadi'ah berarti meningalkan, titipan atau kepercayaan. Para ahli fiqih sepakat wadi'ah hanya sebagai amanah yang tidak dipertanggungjawabkan. Secara istilah, wadi'ah adalah harta yang dititipkan kepada pihak yang mau mengamalkannya tanpa dibebani biaya sedikitpun/sepeserpun. Wadi'ah juga berarti barang/harta yang dititipkan kepada seseorang dengan tujuan barang tersebut aman dan kembali dalam keadaan utuh. ${ }^{83}$ Jadi wadi'ah adalah akad penitipan dari pihak yang mempunyai uang atau barang kepada pihak yang menerima titipan dengan catatan kapanpun titipan dapat diambil pihak penerima titipan wajib menyerahkan kembali uang atau barang titipan tersebut dan yang dititipi menjadi penjamin pengambilan barang titipan. Dalam akad hendaknya dijelaskan tujuan wadi'ah, cara penyimpanan, lamanya waktu penitipan, biaya yang

\footnotetext{
${ }^{82}$ ISRA, Sistem Keuangan Islam: Prinsip dan Operasi, Jakarta Pers, 2015.

${ }^{83}$ Ahmad Dahlan, Bank Syari'ah: Teoritik, Praktik, Kritik, Yogyakarta: Pers, 2012.
} 
dibebankan pada pemilik barang dan hal-hal lain yang dianggap penting. ${ }^{84}$

Akad berpola titipan wadi'ah ada dua, yaitu Wadi'ah Yad Amanah dan Wadi'ah Yad Dhamanah. Pada awalnya, wadi' ah muncul dalam bentuk Yad Al-Amanah "tangan amanah", yang kemudian dalam perkembangan memunculkan Yadh-Dhamanah "tangan penanggung". Akad wadi'ah yad dhamanah ini akhirnya banyak dipergunakan dalam aplikasi perbankan syari' ah dalam produk-produk pendanaan. ${ }^{85}$ Dalam islam wadi'ah dapat dibedakan menjadi dua macam, yaitu:

1) Wadi'ah Yad Amanah yaitu barang yang dititipkan sama sekali tidak boleh digunakan oleh pihak yang menerima titipan, sehingga dengan demikian pihak yang menerima titipan tidak bertanggung jawab terhadap resiko yang menimpa barang yang dititipkan. Penerima titipan hanya punya kewajiban mengembalikan barang yang dititipkan pada saat yang diminta oleh pihak yang menitipkan secara apa adanya. Karakteristik Wadi'ah Yad Amanah sebagai berikut: ${ }^{86}$

a. Barang yang dititipkan oleh nasabah tidak boleh dimanfaatkan oleh pihak penerima titipan.

b. Penerima titipan berfungsi sebagai penerima amanah yang harus menjaga dan memelihara barang titipan, sehingga perlu menyediakan tempat yang aman dan petugas yang menjaganya.

c. Penerima titipan diperkenankan untuk membebankan biaya atas barang yang dititipkan, hal ini karena penerima titipan perlu menyediakan tempat untuk menyimpan dan membayar biaya gaji pegawai untuk menjaga barang titipan, sehingga boleh meminta imbalan jasa.

\footnotetext{
${ }^{84}$ Sri Nurhayati dan Wasilah, Akuntansi Syari'ah di Indonesia, edisi 3, Jakarta: Salemba Empat, 2014.

${ }^{85}$ Ascarya, Akad \& Produk Bank Syari'ah, Jakarta: PT. Raja Grasindo Persada 2008.

${ }^{86}$ Ismail, Perbankan Syari'ah, Jakarta: Kencana Prenadamedia Group, 2014
} 
2) Wadi'ah Yad Dhamanah adalah penitipan barang yang dapat dipergunakan atau dimanfaatkan oleh penerima titipan. Sehingga pihak penerima titipan bertangung jawab terhadap resiko yang menimpa barang sebagai akibat dari penggunaan atas suatu barang, seperti resiko kerusakan dan sebagainya. Tentu saja penerima titipan wajib mengembalikan barang yang dititipkan pada saat diminta oleh pihak yang menitipkan. ${ }^{87}$ Dan tentunya pihak penerima titipan dalam hal ini mendapatkan bagi hasil dari penitip uang atau barang. Dan penerima titipan dapat memberikan intensif kepada penitip dalam bentuk bonus. Karakteristik Wadi'ah Yad Dhamanahsebagai berikut: ${ }^{88}$

a. Harta dan barang yang dititipkan boleh dimanfaatkan oleh pihak penerima titipan.

b. Penerima titipan sebagai pemegang amanah.

c. Barang yang dititipkan boleh dimanfaatkan, namun penerima titipan harus memanfaatkan barang titipan yang dapat menghasilkan.

d. Bank mendapat manfaat atas harta yang dititipkan, oleh karena itu penerima titipan boleh memberikan bonus. Bonus sifatnya tidak mengikat, sehingga dapat diberikan atau tidak. Besarnya bonus tergantung pada pihak penerima titipan. Bonus juga tidak boleh diperjanjikan pada saat kontrak atau akad, karena bukan merupakan kewajiban bagi penerima titipan.

e. Dalam aplikasi bank syari'ah, produk yang sesuai dengan akad wadi'ah yad dhamanah adalah simpanan giro dan tabungan.

${ }^{87}$ Trisandi P. Usanti dan Abd. Shomad, Transaksi Bank Syari'ah, Jakarta: PT. Bumi Aksara, 2013.

${ }^{88}$ Ismail, Perbankan Syari'ah, Jakarta: Kencana Prenadamedia Droup, 2014.

Volume 6 No.1 Januari 2019 


\section{B. Rukun dan Syarat Wadi'ah}

1) Rukun Wadi'ah

Menurut Hanafiyah, rukun wadi'ah hanya satu, yaitu ijab dan qabul. Sedangkan menurut jumhur ulama, rukun wadi'ah itu ada empat: ${ }^{89}$

a. Barang yang dititipkan (wadi'ah)

b. Orang yang menitipkan (mudi' atau muwaddi')

c. Orang yang menerima titipan (muda' atau mustawda')

d. Ijab qabul (sighat)

2) Syarat-Syarat Wadi'ah

Syarat-syarat wadi'ah berkaitan dengan rukun-rukun yang telah disebutkan di atas, yaitu syarat benda yang dititpkan, syarat sighat, syarat orang yang menitipkan dan syarat orang yang dititipkan, syarat orang yang menitipkan dan syarat orang yang dititipi.

a. Syarat-syarat untuk benda yang dititipkan sebagai berikut:

1) Benda yang dititipkan disyaratkan harus benda yang bisa untuk disimpan. Apabila benda tersebut tidak bisa disimpan, seperti burung di udara atau benda yang jatuh ke dalam air, maka wadi'ah tidak sah sehingga apabila barang hilang, tidak wajib mengganti. Syarat ini dikemukakan oleh ulama-ulama Hanafiyah.

2) Syafi'iyah dan hanabilah mensyaratkan benda yang dititipkan harus benda yang mempunyai nilai (qimah) dan dipandang sebagai mal, walaupun najis. Seperti anjing yang bisa dimanfaatkan untuk berburu, atau menjaga keamanan. Apabila benda tersebut tidak memiliki nilai seperti anjing yang tidak ada manfaatnya, maka wadi'ah tidak sah.

b. Syarat-syarat sighat

Sighat akad adalah ijab dan qabul. Syarat sighat adalah ijab harus dinyatakan dengan ucapan atau perbuatan. Ucapan adakalanya tegas (sharih) dan adakalanya dengan sindiran

${ }^{89}$ Ahmad Wardi Muslich, Fiqih Muamalah, Jakarta: Amzah, 2010. 
(khinayah). Malikiyah menyatakan bahwa lafal dengan kinayah harus disertai dengan niat. Contoh lafal yang sharih: "saya titipkan barang ini kepada anda", sedangkan contoh lafal kinayah, seseorang mengatakan: "berikan kepadaku mobil ini". Pemilik mobil menjawab: "saya berikan mobil ini kepada anda ", kata berikan mengandung arti hibah dan wadi'ah (titipan). Dalam konteks ini arti yang paling dekat adalah titipan. Contoh ijab dengan perbuatan: seseorang menaruh sepeda motor dihadapan orang tanpa mengucapkan kata-kata apapun. Perbuatan tersebut menunjukkan penitipan (wadi'ah). Demikian pula pada qabul, kadang-kadang dengan lafal yang tegas (sharih), seperti: "saya terima" dan adakalanya dengan diamlah (penunjukan), misalnya sikap diam ketika barang ditaruh dihadapannya.

c. Syarat orang yang menitipkan (Al-Mudi')

1) Berakal, dengan demikian, tidak ah wadi'ah dari orang gila dan anak yang belum berakal.

2) Baligh, syarat ini dikemukakan oleh syafi'iyah dengan demikian wadi'ah tidak sah apabila dilakukan oleh anak yang belum baligh (masih dibawah umur). Tetapi menurut hanafiyah baligh tidak menjadi syarat wadi'ah sehingga wadi'ah hukumnya sah apabila dilakukan oleh anak mumayyiz dengan persetujuan dari walinya atau washiynya.

d. Syarat orang yang dititipi $\left(A l-M u d a^{\prime}\right)$

1) Berakal, tidak sah wadi'ah dari orang gila dan anak masih bawah umur. Hal ini dikarenakan akibat hukum dari akad ini adalah kewajiban menjaga harta, sedangkan orang yang tidak berakal tidak mampu untuk menjaga barang yang dititipkan kepadanya.

2) Baligh, syarat ini dikemukakan oleh jumhur ulama'. Akan tetapi hanafiyah tidak menjadikan baligh sebagai syarat untuk orang yang dititipi, melainkan cukup ia sudah mumayyiz. 
3) Malikiyyah mensyaratkan orang yang dititipi harus orang yang diduga kuat mampu menjaga barang yang dititipkan kepadanya.

\section{Landasan Hukum Wadi'ah}

Landasan syaria't dan ketentuan tentang sertifikat wadi'ah bank Indonesia diatur dalam fatwa dewan syari'ah nasional nomor 36/DSN-MUI/X/2002 tentang sertifikat wadi'ah bank indonesia tanggal 23 oktober 2002, dimana dalam fatwa tersebut sebagai landasan syari'ah (himpunan fatwa, edisi kedua, hal 233-236) adalah sebagai berikut:

1) Landasan Hukum dari Al-Qur'an:

a. Firman Allah SWT. QS. An-Nisa (4) : 58

Yang artinya: "Sesunguhnya Allah menyuruh kamu menyampaikan amanat kepada yang berhak menerimanya, dan (menyuruh kamu) apabila menetapkan hukum diantara manusia supaya kamu menetapkan dengan adil. Sesungguhnya Allah adalah Maha mendengar lagi Maha melihat."

b. Firman Allah SWT. QS. Al-Maidah (5) : 1

Yang artinya : Wahai orang-orang yang beriman, penuhilah akad kalian..."

c. Firman Allah SWT. QS. An-Nisa': 6

Yang artinya : "Kemudian apabila kamu menyerahkan harta kepada mereka, maka hendaklah kamu adakan saksi-saksi (tentang penyerahan itu) bagi mereka." 90

2) Landasan Hukum dari Hadist. Hadist iwayat Abu Dawud dan Al Tirmidzi Yang artinya : "Tunaikanlah amanat itu kepada orang yang memberi amanat kepadamu dan janganlah kamu mengkhianati orang yang mengkhianatimu. $" 91$

3) Hukum Menerima Benda Titipan

\footnotetext{
${ }^{90}$ Mujamma' Khadim Al Haramin As Syarifain, Terjemahan Al-Qur'an Ma'aniyah Ila Lughotil Indonesia

${ }^{91}$ Syeh Taqiyudin Abu Bakar Bin Muhammad Al Husaini, Kifayatul Ahyar, Surabaya: Darul Ilmi
} 
Hukum menerima benda titipan ada empat macam yaitu sunat, haram, wajib, dan makruh. Secara lengkap akan dijelaskan sebagai berikut :

a. Sunat, disunatkan menerima titipan bagi orang yang percaya kepada dirinya bahwa dia sanggup menjaga benda-benda yang dititipkan kepadanya. Wadi'ah adalah salah satu bentuk tolong menolong yang diperintahkan oleh Allah dalam Al-Qur'an, tolong menolong secara umum hukumnya sunat. Hal ini dianggap sunat menerima benda titipan ketika ada orang lain yang pantas untuk menrima titipan.

b. Wajib, diwajibkan menrima benda-benda titipan bagi seseorang yang percaya bahwa dirinya sanggup menrima dan menjaga benda-benda tersebut, sementara orang lain tidak ada seorangpun yang dapat dipercaya untuk memelihara benda-benda tersebut.

c. Haram, apabila seseorang tidak kuasa atau tidak sanggup memelihara benda-benda titipan. Bagi orang seperti itu diharamkan menerima benda-benda titipan, sebab dengan menerima benda-benda titipan , berarti m,emberi kesempatan (peluang) kerusakan atau hilangnya bendabenda titipan tersebut, sehingga akan menyulitkan pihak yang menitipkan.

d. Makruh, bagi orang yang percaya kepada dirinya sendiri bahwa dia mampu menjaga benda-benda titipan, tetapi dia kurang yakin atau ragupada kemampuannya, maka bagi orang seperti ini makruh hukumnya menerima bendabenda titipan, sebab dikhawatirkan dia akan berkhianat terhadap yang menitipkan dengan cara merusak benda titipan atau menghilangkannya. ${ }^{92}$

${ }^{92}$ Ismail Nawawi, Fiqih Muamalah Klasik dan Kontemporer Hukum Perjanjian Ekonomi, Bisnis, dan Solusi . Bagor: Ghalia Indonesia, 2012. 


\section{Gambaran Umum Produk Simpanan Idul Fitri}

Simpanan idul fitri adalah simpanan rutin setiap bulan selama 12 bulan sebagai dana persiapan menyambut hari raya idul fitri dengan nominal simpanan untuk awal pembukaan tabungan yaitu Rp. 10.000,- dan angsuran perbulan tidak ditetapkan berapa harus membayarnya (bebas). Simpanan idul fitri merupakan salah satu simpanan yang menggunakan akad wadi'ah yang penarikannya dilakukan sesuai perjanjian yaitu selama 12 bulan sekali. ${ }^{93}$

Simpanan idul fitri merupakan salah satu produk unggulan LKMA, karena sejak diluncurkannya selalu mendapatkan respon yang positif dari masyarakat dan anggota simpanan idul fitri indikatornya adalah bahwa setiap periode selalu mengalami penambahan peserta. Simpanan idul fitri merupakan dana semi permanen dan dapat dijadikan modal kerja dengan jangka waktu maksimal 10 bulan. Simpanan idul fitri pertama kali dilakukan pada tahun 2009 dan terus berkembang hingga sekarang. perkembangan simpanan idul fitri bisa dilihat pada tabel.

\begin{tabular}{|c|c|r|}
\hline Periode & Jumlah Peserta & Setoran Perbualan \\
\hline 1 & 70 & 30.000 sampai 50,000 \\
\hline 2 & 105 & 30.000 sampai 60.000 \\
\hline 3 & 140 & 40.000 sampai 60.000 \\
\hline 4 & 168 & 40.000 sampai 60.000 \\
\hline 5 & 203 & 40.000 sampai 60.000 \\
\hline 6 & 244 & 50.000 sampai 60.000 \\
\hline 7 & 286 & 50.000 sampai 60.000 \\
\hline 8 & 324 & 50.000 sampai 70.000 \\
\hline 9 & 352 & 50.000 sampai 100.000 \\
\hline 10 & 411 & 50.000 sampai 100.000 \\
\hline
\end{tabular}

Tabel Perkembangan Simpanan Idul Fitri

Perkembngan simpanan idul fitri sejak awal pembukaan tahun 2009 yaitu dari periode ke-1 sampai dengan periode ke-9 mengalami

${ }^{93}$ Buku Petunjuk Teknis tentang Pembiayaan dan Simpanan LKMA Syari'ah Amanah Mandiri. 
peningkatan yang cukup tinggi dari tahun ke tahun. Sedangkan pada tahun 2018 ini sedang memasuki periode ke-10 dan jumlah anggota sudah mendaftar mencapai 411 orang. ${ }^{94}$

1. Tujuan dan Manfaat Simpanan Idul Fitri

Simpanan Idul Fitri LKMA Syari'ah Amanah Mandiri memiliki tujuan sebagai berikut:

a. Menghimpun dana masyarakat yang berminat untuk menabung.

b. Memahami kebutuhan masyarakat saat menjelang hjari raya idul fitri.

Sedangkan manfaat simpanan idul fitri adalah sebagai berikut:

a. Aman dan Terjamin, anggota akan merasa aman karena pihak LKMA menjaga dan menjamin dana anggota serta mengembalikan dana angota tepat waktu.

b. Bonus dan Hadiah, di akhir periode simpanan, anggota simpanan idul fitri akan mendapatkan bonus serta hadiah menarik berupa peralatan rumah tangga yang dapat didapatkan angota yang beruntung mendapatkan undian.

2. Ketentuan-ketentuan Simpanan Idul Fitri ${ }^{95}$

a. Anggota wajib melakukan setoran simpanan sesuai kemampuan nasabah setiap bulan maksimal tanggal 15 setiap bulannya.

b. Anggota dapat mengikuti lebih dari satu paket simpanan idul fitri dan akan mendapatkan kesempatan lebih besar untuk memenangkan hadiah.

c. Anggota yang memenuhi ketentuan setoran rutin berhak dalam undian berhadiah.

d. Angota yang tidak melakukan setoran 2 bulan berturut-turut dianggap mengundurkan diri dan tidak dapat mengikuti undian hadiah.

3. Prosedur Pelaksanaan Simpanan Idul Fitri

\footnotetext{
${ }^{94}$ Wawancara dengan Bpk. Puspito selaku Manajer LKMA Syari'ah Amanah Mandiri.

${ }^{95}$ Brosur Simpanan Idul Fitri LKMA Syari'ah Amanah Mandiri.
}

Volume 6 No.1 Januari 2019 
Untuk prosedur pelaksanaan simpanan idul fitri yang akan dijelaskan oleh penulis yaitu: prosedur pembukaan tabungan, prosedur penyetoran dan prosedur pelaksanaan undian hadiah.

4. Prosedur pembukaan rekening simpanan idul fitri

Memiliki dan menyerahkan identitas diri berupa, WNI: Foto copy KTP/SIM yang masih sah dan berlaku. WNA: Paspor yang dilengkapi dengan kartu izin menetap sementara (KIMS) atau kartu izin tetap (KITAP), apabila terdapat perbedaan dengan alamat tinggal tetap dengan yang terera pada dokumen tersebut di atas, maka calon anggota harus melengkapi informasinya mengenai alamat tetap tersebut. Untuk calon nasabah yang bukan perorangan menyerahkan foto copy legalitas perusahaan yang bentuk hukumnya diatur dengan peraturan-peraturan oerundangundangan.

Calon nasabah bisa menanyakan mengenai hal-hal sebagai berikut:

1) Keamanan dalam menyimpan uang dalam bentuk produk simpanan idul fitri.

2) Keuntungan yang akan diterima.

Atas pertanyaan tersebut, bagian CS menjelaskan tentang produk simpanan idul fitri kepada calon nasabahnya bahwa menyimpan uang dalam koperasi syari'ah dalam produk simpanan idul fitri yang berakat wadi'ah ini adalah aman karena dijamin oleh LPS. Serta mendapatkan bonus dan hadiah pada akhir periode simpanan.

Mengisi formulir pembukaan simpanan idul fitri, menyerahkan setoran awal Rp. 10.000,- dan bagian administrasi menginput pada data ke komputer dan kemudian mencetak buku tabungan.

5. Jangka Waktu Penyetoran

a. Jangka waktu satu periode simpanan idul fitri adalah 12 bulan.

b. Setiap anggota harus membayar angsuran sesuai keinginan/kemampuan nasabah perbualan sesuai tanggal yang telah ditetapkan.

c. Penyetoran dapat dilakukan dikantor LKMA yang ada di Desa Sekarputeh. 
6. Teknis Pengundian Hadiah

a. Pengundian dilakukan pada saat dua minggu setelah hari raya idul fitri atau hari ke 14 bulan syawal.

b. Pengundian dilakukan dengan sebuah alat pengundian yang didalamnya terdapat 4 buah bola pimpong yang diberi nomor sesuai dengan jumlah anggota.

c. Pengundian dilakukan oleh bagian pendanaan disaksikan oleh beberapa orang sebagai saksi.

d. Dari nomor-nomor pengundian itulah dapat diketahui siapa anggota yang akan mendapatkan hadiah.

7. Daftar Perolehan Hadiah ${ }^{96}$

a. 1 unit lemari es dua pintu.

b. 1 unit TV berwarna.

c. 3 unit handphone kamera.

d. 3 unit kompor gas.

e. 3 unit magic jar.

f. 3 unit stand fan.

g. 8 paket uang tunai @Rp. 150.000,-

h. 8 paket uang tunai @Rp.100.000,-

\section{E. Penerapan Akad Wadi'ah Yad Dhamanah pada Simpanan Idul Fitri}

Pada dasarnya konsep penerapan akad wadi'ah yad dhamanah yaitu pihak yang menerima titipan boleh menggunakan dan memanfaatkan uang atau barang yang di titipkan, sebagai konsekuensi dari akad wadi'ah yad dhamanah, semua keuntungan yang dihasilkan dari dana titipan tersebut menjadi milik LKMA, dan LKMA tidak dilarang untuk memberikan semacam insentif berupa bonus dengan catatan tidak disyaratkan sebelumnya dan tidak ditetapkan dalam nominal, tetapi betul-betul merupakan kewenangan manajemen LKMA. $^{97}$

\footnotetext{
${ }^{96}$ Brosur Simpanan Idul Fitri LKMA Syari'ah Amanah Mandiri.

${ }^{97}$ Antonio, Bank....
} 
Penerapan akad wadi'ah yad dhamanah pada LKMA dapat berupa produk giro dan simpanan qurban. Namun karena di LKMA tidak diperkenankan dengan adanya giro, maka sebagai gantinya, penerapan akad wadi'ah yad dhamanah bisa melalui produk simpanan. Adapun penerapan akad wadi'ah pada produk simpanan idul fitri yaitu; a) Simpanan idul fitri merupakan akad wadi'ah yad dhamanah yang berdasarkan pada prinsip saving account (tabungan berjangka) karena simpanan dan penarikannya hanya dapat dilakukan pada waktu tertentu sesuai dengan kesepakatan antara LKMA dan anggotanya. b) Karena simpanan idul fitri ini menggunakan akad wadi'ah yad dhamanah maka pihak LKMA dapat menggunakan dan memanfaatkan dana tersebut untuk keperluan koperasi misalnya untuk pembiayaan. Selain itu dana yang mengendap juga bisa digunakan sebagai dana likuiditas produk simpanan lainnya yang dimiliki oleh LKMA. ${ }^{98}$

Sesuai dengan prinsipnya, pihak LKMA tidak diharuskan untuk memberikan bonus kepada si pemilik titipan. Namun dalam hal ini, LKMA memberikan bonus kepada anggota tabungan dengan syarat yaitu jika anggota telah melunasi seluruh iuran kolektif selama 12 bulan. LKMA Syari'ah Amanah Mandiri berhak sepenuhnya mendapatkan keuntungan dari hasil pemanfaatan dan penggunaan dana simpanan idul fitri. Sebagai timbal baliknya maka LKMA harus bertanggung jawab terhadap keutuhan harta titipan tersebut serta mengembalikannya sesuai dengan waktu yang telah disepakati antara LKMA dan anggota Simpanan Idul Fitri.

Dalam akad wadi'ah ini memiliki ketentuan-ketentuan umum missal: pertama, tabungan wadi'ah merupakan tabungan yang bersifat titipan murni yang harus dijaga dan dikembalikan setiap saat sesuai dengan kehendak pemilik harta. Kedua, keuntungan atau kerugian dari penyaluran atau pemanfaatan dana menjadi milik atau tabungan bank, sedangkan nasabah penitip tidak dijanjikan imbalan dan tidak menanggung kerugian. Ketiga, Bank dimungkingkan memberikan

\footnotetext{
${ }^{98}$ Wawancara dengan Bpk. Puspito selaku Manajer dari LKMA Syari'ah Amanah Mandiri
} 
bonus kepada pemilik titipan sebagai sebuah insentif selama tidak diperjanjikan di dalam akad pembukaan rekening. ${ }^{99}$

Dari ketentuan-ketentuan akad wadi'ah di atas. Pihak LKMA memang tidak diharuskan memberikan bonus, namun bank dimungkinkan memberikan bonus sebagai insentif untuk menarik dana dari masyarakat. Ketentuan bonus pada simpanan idul fitri bersifat tidak mengikat karena bonus tergantung dari perolehan keuntungan dari pemanfaatan dana yang digunakan, namun dengan syarat anggota sudah melunasi simpanan tabungan selama 12 bulan. Pemeberian bonus pada akad wadi'ah sebenarnya tidak boleh diperjanjikan di awal, tetapi pemberian bonus sepenuhnya merupakan hak dari pihak LKMA karena pada prinsipnya dalam akad wadi'ah ini penekanannya adalah titipan. Apabaila bonus diperjanjikan ditakutkan akan ada permasalahan misalnya jika pihal LKMA tidak mendapatka keuntungan dari pemanfaatan simpanan dul fitri atau dengan kata lain LKMA mengalami kerugian. Oleh karena ini sudah menjadi konsekuensi, maka LKMA harus tetap memberikan bonus kepada anggotanya.

Bonus yang diberikan LKMA boleh di bilang sebagai insentif dalam upaya menambah semangat para anggotanya dalam menabung. Dengan adanya pemberian bonus bisa juga dijadikan sebagai tolak ukur kesuksesan LKMA dalam melaksanakan produk-produknya sehingga dapat meningkatkan reputasi LKMA Syari'ah Amanah Mandiri.

Setelah peneliti menjelaskan tentang gambaran umum produk simpanan idul fitri di LKMA Syari'ah Amanah Mandiri, pada bagian ini peneliti akan menganalisis berdasarkan analisis SWOT untuk mengetahui kekuatan, kelemahan, peluang, dan ancaman dari produk simpanan idul fitri di LKMA Syari'ah Amanah Mandiri.

1. Kekuatan (strenght) yaitu bebas biaya administrasi bulalan, layanan jemput bola, banyaknya dukungan masyarakat, leluasa dalam pengelolahan dana, dan banyak hadiah yang tertawakan.

\footnotetext{
${ }^{99}$ Wawancara dengan Bpk. Puspito selaku Manajer LKMA Syari’ah Amanah Mandiri
} 
2. Kelemahan (weakness) yaitu bonus sudah ditetapkan pada awal abad, terbatasnya jaringan peayanan, dan bonus atau hadiah.

3. Peluang (opportunitess) yaitu pangsa pasar masih positif, lokasi strategi, antusias masyarakat tinggi.

4. Ancaman (theats), ancaman disini meliputi faktor internal dan eksternal. Faktor internal yang menjadi ancaman adalah ketidak mampuan LKMA dalam memanfaatkan kekuatan dan peluang yang ada. Sehingga yang terjadi kekuatan dan peluan tersebut bisa berubah menjadi ancaman besar bagi LKMA. Sedangkan faktor eksternal yang menjadi ancaman simpanan idul fitri. Pertama, banyaknya produk tabungan yang sejeni. Kedua, apabila adanya koperasi syari'ah yang muncul lagi di desa sekarputeh. Ketiga, keadaan ekonomi desa yang tidak menentu.

Meski demikian, ada upaya-upaya yang dilaksanakan oleh LKMA berdasarkan hasil analisis SWOT diatas yaitu: a) Upaya dalam hal memaksimalkan kekuatan untuk memanfaatkan peluang (S-O) dengan terus meningkatkan layanan LKMA, memperkuat kerja dengan mitra, tetap menjadi lembaga keuangan syari'ah yang amanah. b) Usaha dalam meminimilasir kelemahan dengan memanfaatkan peluang (W-O) yaitu dengan meningkatkan layanan jemput bola, pemberian hadiah yang lebih menarik. c) Upaya memaksimalkan kekuatan untuk menghadapi tantangan (S-T) yaitu dengan membuat produk simpanan idul fitri lebih berbeda dan lebih unggul, menetapkan target pemasaran. d) Upaya memperkecil kelemahan dan mengatasi tantangan (W-T) yaitu dengan memaksimalkan SDM dengan perekrutan karyawan baru, memberikan pelatihan terhadap karyawan, berusaha memberikan pemahaman syari'ah kepada mitra.

\section{Kesimpulan}

Berdasarkan pembahasan pada bab-bab sebelumnya, maka penulis menarik beberapa kesimpulan, yang pertama yaitu simpanan idul fitri merupakan simpanan rutin setiap bulan selama 12 bulan sebagai dana persiapan menyambut hari raya idul fitri dengan nominal simpanan perbulan tergantung keinginan nasabah ingin menyimpan berapa. Simpanan merupakan salah satu simpanan yang menggunakan 
akad wadi'ah yang penarikannya dilakukan sesuai perjanjian yaitu selama 12 bulan sekali. Kedua, dengan akad wadi'ah yad dhamanah, maka LKMA dapat memanfaatkan dan mengelola dana yang telah terhimpun dari anggota untuk keperluan LKMA dalam produk pembiayaan. Dari keuntungan yang telah dihasilkan dari pengelolaan dana tersebut., LKMA bisa memberikan bonus dan hadiah kepada anggota anggotanya sesuai dengan keuntungan yang di dapat. Ketiga, kelebihan dari produk simpanan idul fitri antara lain: bebas biaya administrasi, angsuran tiap bulan yang di bebaskan berapa ingin mengangsur, menggunakan layanan jemput bola, banyaknya dukungan masyarakat, dan banyak hadiah yang ditwarkan. Sedangkan kekurangannya karna terbatasnya jaringan pelayanan, bonus dan hadiahnya hanya bisa diberikan kepada anggota yang sudah melunasi semua setoran selama 12 bulan.

\section{Daftar Pustaka}

Ahmad Dahlan, Bank Syariah: Teoritik, Praktik, Kritik, Yogyakarta: Teras, 2012

Ahmad Wardi Muslich, Fiqih Muamalah, Jakarta: Amzah, 2010

Ascarya, Akad \& Produk Bank Syari'ah, Jakarta: PT. Raja Grasindo Persada 2008

Buku Petunjuk Teknis tentang Pembiayaan dan Simpanan LKMA Syari'ah Amanah Mandiri

Brosur Simpanan Idul Fitri LKMA Syari'ah Amanah Mandiri

Djoko Muljono, Buku Pintar Strategi Bisnis Koperasi Simpan Pinjam, Yogyakarta: Andi, 2012

Harian Bisnis News, Hari Senin 02 April 2018

Ismail Nawawi, Fiqih Muamalah Klasik dan Kontemporer Hukum Perjanjian Ekonomi, Bisnis, dan Solusi. Bagor: Ghalia Indonesia, 2012

ISRA, Sistem Keuangan Islam: Prinsip dan Operasi. Jakarta: Rajawali Pers, 2015

Majelis Ulama Indonesia "Keputusan Dewan Syari'ah NO. 1 Tahun 2000" Dasar Pemikiran ke-3 
Margono, Metodologi Penelitian Kualitatif, (Jakarta: Rineka Cipta, 1996)

Miles, dkk, Analisis Data Kualitatif. Terjemahan: Tjejep RR (Jakarta: UI Press, 1992)

Mujamma' Khadim Al Haramin As Syarifain, Terjemah Al-Qur'an Ma'aniyah Ila Lughotil Indonesia

Mutimatun Nia'mi, SH. Kuliah Muamalah. Fakultas Hukum Universitas Muhammadiyah Surakarta, Tahun ajaran 20122013

Modul LKMA Syari'ah Amanah Mandiri

Moleong Lexy, Metodologi Penelitian Kualitatif, Bandung: Remaja Rosdakarya, 2009

Nana Staodih Sukmadinata, Metodologi Penelitian Kualitatif, Bandung: Remaja Rosdakarya, 2009

Nasution, Metode Reseach, Jakarta: Bumi Aksara, 2006

Sri Nurhayati dan Wasilah, Akuntansi Syari'ah di Indonesia, edisi 3, Jakarta: Salemba Empat, 2014

Suharsimi Arikunto, Prosedur Penelitian, Jakarta: PT. Asdi Mahasatya, 2006

Trisadini P. Usanti dan Abd. Shomad, Transaksi Bank Syari'ah, Jakarta: PT. Bumi Aksara, 2013

Wawancara dengan Bpk. Puspito selaku Manajer LKMA Syari'ah Amanah Mandiri 